\title{
ZASADY MEDIACJI W ROZWIAZYWANIU KONFLIKTÓW ORGANIZACYJNYCH W SYSTEMIE LOGISTYCZNYM PRZEDSIĘBIORSTWA
}

DOI: $10.33141 /$ po.2019.11.02

\author{
Andrzej Kozina, Tomasz Małkus, Agnieszka Pieczonka
}

\section{Wprowadzenie}

W systemie logistycznym przedsiębiorstwa występuje wiele różnorodnych konfliktów pomiędzy współdziałającymi pracownikami i zespołami, zwykle dużo więcej niż $\mathrm{w}$ innych podsystemach firmy. Jest to spowodowane przede wszystkim znacznym zróżnicowaniem i zmiennością zadań realizowanych $\mathrm{w}$ tym systemie oraz wielością różnego rodzaju relacji zarówno pomiędzy wewnętrznymi jednostkami organizacyjnymi, jak i z zewnętrznymi interesariuszami. Jednym $\mathrm{z}$ istotnych narzędzi rozwiązywania omawianych konfliktów jest mediacja, realizowana przede wszystkim przez menedżerów nadzorujących działania wspomnianych jednostek organizacyjnych.

Przedmiotem badań w niniejszym artykule jest mediacja jako narzędzie rozwiązywania konfliktów organizacyjnych w systemie logistycznym przedsiębiorstwa, a ściślej zasady jej prowadzenia. Celem badań jest $\mathrm{z}$ jednej strony sformułowanie tego rodzaju zasad, a $\mathrm{z}$ drugiej - sprawdzenie ich przydatności w praktyce. Prace te stanowią rozwinięcie części szerszych badań porównawczych, będących przedmiotem rozprawy doktorskiej współautorki, w ramach których opracowano i zweryfikowano w praktyce model zarządzania rozważanymi konfliktami, obejmujący ich następujące wymiary: rodzaje, uwarunkowania, następstwa (pozytywne, tj. funkcje, i negatywne, czyli skutki) oraz narzędzia kierowania nimi (w tym zasady mediacji).

Zamierzeniem autorów artykułu było zatem sprawdzenie, czy i jakim zakresie oraz $\mathrm{z}$ jakim skutkiem proponowane zasady mediacji mogą być przydatne jako narzędzia rozwiązywania omawianych konfliktów. Podstawowe narzędzie badawcze stanowił kwestionariusz ankiety, na którą udzielili odpowiedzi pracownicy logistyki z kilkudziesięciu różnorodnych przedsiębiorstw w Polsce ${ }^{1}$.

O podjęciu prezentowanych badań zadecydowały trzy przesłanki: luka teoretyczna w zakresie zarządzania rozważanymi konfliktami, duże praktyczne zapotrzebowanie na użyteczne narzędzia kierowania nimi oraz zainteresowania własne autorów.

Jeśli chodzi o pierwszą, najważniejszą, z wymienionych przesłanek, to należy podkreślić, iż w literaturze przedmiotu stosunkowo rzadko podejmuje się omawianą problematykę w ogóle, a w zakresie zasad mediacji w rozwiązywaniu konfliktów w szczególności (jedynie w ograniczonym zakresie). Ponadto w większości opracowań problematykę tę rozważa się w kontekście funkcjonowania łańcuchów logistycznych, a nie w odniesieniu do wyodrębnionej działalności logistycznej pojedynczego przedsiębiorstwa. Jako przykłady omawianych prac można wymienić następujące pozycje: (Handfield, Baumer, 2006; Barutçu, Doöan, Barutçu, Kulakli, 2010; Wallenburg, Raue, 2011; John, Prasad, 2012; Pereseina, Jensen, Hertz, $\mathrm{Cu}, 2014$ ), a wśród polskich opracowań: (Kisperska-Moroń, 1999; Długosz, 2000; Krysiuk, Zakrzewski, Zakrzewska, 2014; Zakrzewski, Zakrzewska, 2014).

Biorąc pod uwagę powyższe stwierdzenia, przyjęto hipotezę badawczą, iż proponowane zasady mediacji stanowią użyteczne narzędzia praktycznego rozwiązywania konfliktów organizacyjnych w systemie logistycznym przedsiębiorstwa.

\section{Podstawy teoretyczne badań dotyczących mediacji w rozwiązywaniu konfliktów organizacyjnych w systemie logistycznym przedsiębiorstwa}

U

znając za zbędne szersze rozważania, a tym bardziej dyskusje terminologiczne, przyjęto następujące interpretacje czterech kluczowych pojęć występujących w artykule.

1. System logistyczny przedsiębiorstwa (w najogólniejszym rozumieniu) stanowi celowo zorganizowaną, zintegrowaną i spójną całość (zespół) złożoną z takich głównych podsystemów (elementów), jak: zaopatrzenie, produkcja oraz dystrybucja (w tym magazynowanie), a także rynki zbytu (odbiorców) i zaopatrzenia (dostawców), zwrotu towarów, odpadów i surowców wtórnych oraz procesy transportu i spedycji - ewentualnie procesy zakupów, sprzedaży, finansowania itp. - wraz z relacjami i zależnościami pomiędzy tymi elementami i ich właściwościami warunkującymi sprawny przepływ strumieni towarów, wspomagany przez adekwatny obieg środków finansowych i informacji. Interpretacja ta odzwierciedla systemowe ujęcie logistyki firmy w odpowiedzi na zmiany rynkowych warunków działania, upowszechnione m.in. w pracach: (Christopher, 2000; Pfohl, 1998; Blaik, 1999), a także uwzględnia przykładowe interpretacje rozważanego pojęcia, np. z opracowań (Garbarski i in., 2000, s. 390; Michlowicz, 2002, s. 84 i 89; Szymonik, Bielecki, 2015, s. 12). 
2. Konflikt organizacyjny w systemie logistycznym przedsiębiorstwa można zdefiniować jako każdego rodzaju nieporozumienie, rozbieżność, sprzeczność, niezgodność, zatarg, antagonizm itp., zarówno pomiędzy stanowiskami pracy (kierowniczymi i wykonawczymi), jak i jednostkami oraz komórkami organizacyjnymi (zespołami) wyodrębnionymi w tym systemie, $\mathrm{w}$ związku $\mathrm{z}$ realizowanymi przez nie procesami i poszczególnymi zadaniami logistycznymi. Podłoże konfliktu, jego charakter i przebieg przekładają się bezpośrednio lub pośrednio na sprawność realizacji zadań i procesów w rozważanym systemie oraz wpływają na wzajemne relacje pomiędzy pojedynczymi pracownikami i ich zespołami, pełniącymi różne funkcje i realizującymi specyficzne zadania w ramach tego systemu. W odniesieniu systemu logistycznego, podobnie jak do wszystkich typowych obszarów działalności firmy, mają oczywiście zastosowanie wszelkiego typu koncepcje i narzędzia metodyczne wykorzystywane w opisie i analizie konfliktów organizacyjnych i zarządzaniu nimi, zawarte w bogatej literaturze przedmiotu, zarówno klasycznej (Killman, Thomas, 1978; Pruitt, Rubin, 1986; Rahim, 1986), jak i współczesnej (Jones, Brinkert, 2008; Cloke, Goldsmith, 2011; Roche i in., 2014).

3. Model zarządzania konfliktami organizacyjnymi w systemie logistycznym przedsiębiorstwa stanowi konstrukcję metodyczną opisująca wszystkie ich wymiary zestawione $\mathrm{w}$ tabeli 1 oraz zależności pomiędzy nimi, które ujęto w tabeli 2 (uznając za zbędne rozważanie pojęcia modelu, lecz przyjmując je intuicyjnie). Trzy pierwsze wymiary są wystarczające dla wszechstronnego wyjaśnienia istoty i natury rozważanych konfliktów (ujęcie deskryptywne), natomiast czwarty wymiar obejmuje zbiór narzędzi zapewniających sprawne kierowanie nimi (ujęcie normatywne).

Tabela 1. Wymiary modelu zarządzania konfliktami organizacyjnymi w systemie logistycznym przedsiębiorstwa

\begin{tabular}{|l|l|}
\hline \multicolumn{1}{|c|}{ Wymiary } & \multicolumn{1}{c|}{ Interpretacja } \\
\hline $\begin{array}{l}\text { Rodzaje } \\
\text { konfliktów }\end{array}$ & $\begin{array}{l}\text { Ich różnorodne przypadki, które mogą wystąpić w systemie logistycznym, tzn. posiadające odmienne od siebie, swoiste cechy, } \\
\text { wyodrębniane przy użyciu różnych kryteriów, przy czym zakłada się, że z punktu widzenia wyjaśnienia ich istoty, rozważane } \\
\text { konflikty powinny być zróżnicowane głównie ze względu na ich podmioty (uczestników), zasoby (determinujące ich przedmiot) } \\
\text { oraz charakter (wyjaśniający ich specyfikę, naturę). }\end{array}$ \\
\hline $\begin{array}{l}\text { Uwarunkowania } \\
\text { konfliktów }\end{array}$ & $\begin{array}{l}\text { Wszelkiego rodzaju przesłanki, powody, czynniki itp., niezbędne do identyfikacji i analizy w organizacji i funkcjonowaniu } \\
\text { systemu logistycznego, a także w relacjach z jego otoczeniem, wywołujące konflikty pomiędzy elementami tego systemu, przy } \\
\text { czym za pierwotne i najważniejsze uważane są uwarunkowania o charakterze strukturalnym. }\end{array}$ \\
\hline $\begin{array}{l}\text { Następstwa } \\
\text { konfliktów }\end{array}$ & $\begin{array}{l}\text { Różnego rodzaju zdarzenia, działania, problemy itp., niezbędne do identyfikacji i analizy w zakresie organizacji } \\
\text { i funkcjonowania systemu logistycznego, a także w relacjach z jego otoczeniem, będące konsekwencją pojawiania się konfliktów } \\
\text { (zaistniałe w ich wyniku), zarówno o charakterze negatywnym - zwane „skutkami”, jak i pozytywnym - określane jako „funkcje”. }\end{array}$ \\
\hline $\begin{array}{l}\text { Narzędzia } \\
\text { kierowania } \\
\text { konfliktami }\end{array}$ & $\begin{array}{l}\text { Różnego rodzaju sposoby oddziaływania na konflikty powstające w systemie logistycznym (podejścia, metody stymulowania, } \\
\text { ograniczania i rozwiązywania, w szczególności negocjacje i mediacje) poprzez podejmowanie niezbędnych działań przez } \\
\text { menedżerów komórek i jednostek organizacyjnych w tym systemie, odpowiedzialnych za kierowanie konfliktami na właściwych } \\
\text { szczeblach hierarchii rozkazodawczej, które to działania powinny być adekwatne do specyfiki danego konfliktu (jego rodzaju, } \\
\text { uwarunkowań i następstw) oraz zapewniać osiągnięcie pożądanego poziomu efektywności funkcjonowania tego systemu. }\end{array}$ \\
\hline
\end{tabular}

Źródło: opracowanie własne

Tabela 2. Zależności pomiędzy wymiarami modelu konfliktów organizacyjnych w systemie logistycznym przedsiębiorstwa

\begin{tabular}{|c|c|c|c|c|c|c|}
\hline \multirow{2}{*}{\multicolumn{2}{|c|}{ Wymiary }} & \multirow{2}{*}{ Rodzaje } & \multirow{2}{*}{ Uwarunkowania } & \multicolumn{2}{|c|}{ Następstwa } & \multirow{2}{*}{$\begin{array}{c}\text { Narzędzia } \\
\text { rozwiązywania }\end{array}$} \\
\hline & & & & Skutki & Funkcje & \\
\hline \multicolumn{2}{|c|}{ Rodzaje } & $\begin{array}{l}\text { wspólne i odmienne } \\
\text { cechy konfliktów }\end{array}$ & $\begin{array}{l}\text { zakres i siła wpływu } \\
\text { na inne, potencjalne } \\
\text { konflikty }\end{array}$ & $\begin{array}{l}\text { zakres i siła } \\
\text { oddziaływania }\end{array}$ & $\begin{array}{l}\text { możliwości } \\
\text { i ograniczenia } \\
\text { stosowania }\end{array}$ & $\begin{array}{l}\text { dobór i potencjalna } \\
\text { skuteczność }\end{array}$ \\
\hline \multicolumn{2}{|c|}{ Uwarunkowania } & $\begin{array}{l}\text { różnicowanie ilości } \\
\text { i cech konfliktów }\end{array}$ & $\begin{array}{l}\text { wzmaganie się } \\
\text { wzajemne }\end{array}$ & rodzaj i istotność & rodzaj i istotność & $\begin{array}{l}\text { dobór i możliwość } \\
\text { zastosowania }\end{array}$ \\
\hline \multirow{2}{*}{ 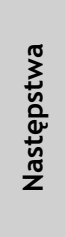 } & Skutki & $\begin{array}{l}\text { występowanie } \\
\text { nowych lub kolejnych } \\
\text { konfliktów }\end{array}$ & $\begin{array}{l}\text { wywoływanie nowych } \\
\text { konfliktów }\end{array}$ & $\begin{array}{l}\text { nasilanie się } \\
\text { wzajemne }\end{array}$ & $\begin{array}{l}\text { ograniczanie } \\
\text { pozytywnej roli }\end{array}$ & $\begin{array}{l}\text { limitowanie } \\
\text { możliwości } \\
\text { stosowania }\end{array}$ \\
\hline & Funkcje & $\begin{array}{l}\text { ograniczanie nowych } \\
\text { lub kolejnych } \\
\text { konfliktów }\end{array}$ & $\begin{array}{l}\text { ograniczanie nowych } \\
\text { konfliktów }\end{array}$ & $\begin{array}{l}\text { ograniczanie } \\
\text { negatywnej roli }\end{array}$ & $\begin{array}{l}\text { nasilanie się } \\
\text { wzajemne }\end{array}$ & $\begin{array}{l}\text { poszerzanie } \\
\text { możliwości } \\
\text { stosowania }\end{array}$ \\
\hline \multicolumn{2}{|c|}{$\begin{array}{l}\text { Narzędzia } \\
\text { rozwiązywania }\end{array}$} & $\begin{array}{l}\text { dostosowanie do } \\
\text { specyfiki konfliktów }\end{array}$ & $\begin{array}{l}\text { nasilanie lub } \\
\text { osłabianie }\end{array}$ & $\begin{array}{l}\text { nasilanie lub } \\
\text { osłabianie }\end{array}$ & $\begin{array}{l}\text { wspomaganie lub } \\
\text { ograniczanie }\end{array}$ & $\begin{array}{l}\text { uzupełnianie lub } \\
\text { wykluczanie się } \\
\text { wzajemne }\end{array}$ \\
\hline
\end{tabular}

Źródło: opracowanie własne 
4. Mediacja to interwencja w przebieg konfliktu, dokonywana przez niezależną, akceptowaną (przez uczestników konfliktu) trzecią (neutralną, niezależną) stronę, która nie posiada kompetencji decyzyjnych, celem pomocy stronom konfliktu w osiągnięciu wzajemnie akceptowanego porozumienia (Moore, 1993, s. 445). Mediacja zapobiega eskalacji konfliktu, która może utrudnić albo wręcz uniemożliwić prawidłowe współdziałanie stron sporu, a co za tym idzie, obniżenie efektywności funkcjonowania firmy. Ma doprowadzić do rozstrzygnięcia albo rozwiązania konfliktu, tj. stworzenia sytuacji akceptowanej przez zaangażowane $\mathrm{w}$ niego strony. $\mathrm{W}$ omawianych pracach badawczych skoncentrowano się na mediacji menedżerskiej, tj. realizowanej przez odpowiednich przełożonych odpowiedzialnych za zarządzanie konfliktami w podległych im zespołach.
Na podstawie analizy porównawczej literatury zaproponowano zestawienie zasad mediacji menedżerskiej zawarte w tabeli 3, które podlegały weryfikacji w badaniach empirycznych.

Specyfika mediacji w kierowaniu rozważanymi konfliktami polega przede wszystkim na tym, iż trzeba dostosowywać sposób jej prowadzenia do specyfiki tych konfliktów, gdyż są one bardzo zróżnicowane, zmienne, a niekiedy nieprzewidywalne. Przykładowo część z nich może mieć charakter niepowtarzalny, jednorazowy (np. przy sporze spowodowanym nagłym wycofaniem się partnera ze współpracy), część - rutynowy (np. powtarzające się rozbieżności pomiędzy wielkościami zapotrzebowania $\mathrm{w}$ obszarach logistyki zaopatrzenia i produkcji). Ponadto, ze względu na dużą dynamikę działania systemów logistycznych często konieczne są szybkie i zdecydowane działania menedżerów jako mediatorów.

Tabela 3. Zasady mediacji menedżerskiej

\begin{tabular}{|c|c|c|}
\hline & Nazwa & Charakterystyka \\
\hline 1 & Zasada perspektywiczności & $\begin{array}{l}\text { Proces mediacji jest zorientowany na przyszłość, a nie na nadmierne roztrząsanie przeszłych spraw } \\
\text { oraz postrzegany w kontekście efektywności działania przedsiębiorstwa. }\end{array}$ \\
\hline 2 & Zasada wyboru właściwego mementu & $\begin{array}{l}\text { Mediator włącza się w proces rozwiązania konfliktu we właściwym czasie. Nie dokonuje } \\
\text { przedwczesnych ingerencji illub nie pozostawia stron konfliktu bez wsparcia, gdy jest ono faktycznie } \\
\text { niezbędne, tj. w zastoju lub impasie. }\end{array}$ \\
\hline 3 & Zasada niezależności (neutralności) & $\begin{array}{l}\text { Mediator jest bezstronny i akceptowany przez strony (nie opowiada się po żadnej z nich) oraz potrafi } \\
\text { zachować niezbędny dystans do nich i do samego konfliktu. }\end{array}$ \\
\hline 4 & Zasada planowania & $\begin{array}{l}\text { Mediator efektywnie aranżuje proces mediacji i wyjaśnia stronom, jakie są ich role oraz czego się od } \\
\text { nich oczekuje. }\end{array}$ \\
\hline 5 & $\begin{array}{l}\text { Zasada wsparcia w rozpoznaniu } \\
\text { problemu }\end{array}$ & $\begin{array}{l}\text { Mediator pomaga stronom właściwie zidentyfikować problemy stanowiące podłoże konfliktu, } \\
\text { eliminując z rozważań kwestie osobowościowe i interpersonalne. }\end{array}$ \\
\hline 6 & Zasada organizacji & Mediator ustala zasady prowadzenia dyskusji i konsekwentnie je stosuje. \\
\hline 7 & Zasada równości stron & Występuje równoprawność stron w całym procesie mediacji. \\
\hline 8 & Zasada obiektywizmu & $\begin{array}{l}\text { Strony mogą swobodnie przedstawić swoje stanowiska i argumenty, bez żadnych ograniczeń } \\
\text { (merytorycznych, czasowych, przestrzennych itp.). }\end{array}$ \\
\hline 9 & Zasada swobody prezentacji & Stanowiska i argumenty stron są przedstawiane w otwartej, rzeczowej i szczerej atmosferze. \\
\hline 10 & Zasada elastyczności & W razie konieczności mediator spotyka się z każdą ze stron z osobna. \\
\hline 11 & Zasada płynności & Wypowiedzi stron nie są z jakiegokolwiek powodu przerywane. \\
\hline 12 & $\begin{array}{l}\text { Zasada wsparcia w tworzeniu } \\
\text { rozwiązań }\end{array}$ & $\begin{array}{l}\text { Mediator wspomaga strony w poszukiwaniu przez nie rozwiązań problemów, inspiruje i zachęca do } \\
\text { kreatywnego działania. }\end{array}$ \\
\hline 13 & Zasada elastyczności & $\begin{array}{l}\text { Każda propozycja rozwiązania konfliktu jest brana pod uwagę, nie lekceważy się i nie odrzuca } \\
\text { jakichkolwiek merytorycznych sugestii stron konfliktu. }\end{array}$ \\
\hline 14 & Zasada reasumpcji & $\begin{array}{l}\text { Mediator podsumowuje wypowiedzi stron, jednocześnie powstrzymując się od przedwczesnych, } \\
\text { pochopnych ocen. }\end{array}$ \\
\hline 15 & Zasada formalizacji porozumienia & $\begin{array}{l}\text { Mediator pomaga w jasnym i jednoznacznym sformułowaniu porozumienia (w razie potrzeby na } \\
\text { piśmie). }\end{array}$ \\
\hline 16 & Zasada rekapitulacji & Mediator obiektywnie ocenia postępowanie stron i przebieg procesu mediacji. \\
\hline 17 & Zasada integracji & $\begin{array}{l}\text { Po rozstrzygnięciu konfliktu mediator gratuluje pracownikom konstruktywnego rozwiązania } \\
\text { konfliktu. }\end{array}$ \\
\hline
\end{tabular}

Źródło: opracowanie wtasne na podstawie bogatej literatury przedmiotu, m.in.: Colosi, 1993; Cousins, Benitz, 1994; Doherty, Guyler, 2008; Moore, 2009), a z prac autorów rodzimych (Bargiel-Matusiewicz, 2014; Gitling, 2013, s. 244-245; Gmurzyńska, Morek, 2018 
Pomimo znaczącego zróżnicowania specyfiki konfliktów, zróżnicowania struktur systemów logistycznych przedsiębiorstw, konieczności uwzględniania zaangażowania zewnętrznych usługodawców w funkcjonowaniu tych systemów menedżerowie są odpowiedzialni za przygotowanie i realizację dostaw zgodnie $\mathrm{z}$ oczekiwaniami odbiorców. W takich warunkach działania trudno jest jednak wypracować stałe, rutynowe sposoby postępowania mediacyjnego. Dodatkowym utrudnieniem mediacji w wewnętrznym systemie logistycznym pojedynczego przedsiębiorstwa może być także potrzeba uwzględnienia warunków działania dostawców i odbiorców podczas integrowania współpracy w łańcuchu dostaw.

\section{Metoda badawcza}

$\mathbf{P}$ odstawowym narzędziem prac badawczych był kwestionariusz ankiety, obejmujący 41 pytań, w większości zamkniętych, uzupełnionych pytaniami otwartymi wtedy, gdy potrzebne było uzyskanie przykładów potwierdzających opinie wyrażane w syntetycznej formie. Ze względu na znaczną obszerność tego kwestionariusza, zawartego w pracy A. Pieczonki (2019, s. 327-345), jego zamieszczenie w niniejszym opracowaniu jest niemożliwe.

Do interesującego nas zagadnienia mediacji menedżerskiej odnosiły się dwa pytania. W pierwszym, zamkniętym poproszono respondentów o dokonanie oceny częstotliwości wykorzystywania zasad mediacji menedżerskiej (ujętych w tabeli 3) w kierowaniu konfliktami, według skali: 5 - bardzo często, 4 - często, 3 - od czasu do czasu, 2 - rzadko, 1 - bardzo rzadko, 0 - wcale. Pytanie drugie (otwarte) sprowadzało się do przedstawienia przykładu mediacji w konflikcie organizacyjnym, który wystąpił w danym systemie logistycznym.

Jako narzędzie ustalenia zakresu badań empirycznych zastosowano dobór celowy, za czym przemawiał zdecydowanie jakościowy i porównawczy charakter tych badań oraz ich bardzo szeroki zakres, obejmujący szereg analizowanych zjawisk, cech i uwarunkowań (w odniesieniu do zdefiniowanych wcześniej wymiarów rozważanych konfliktów). Najbardziej pożądaną grupę docelową stanowiły przedsiębiorstwa duże i średnie, gdyż rozważane problemy uwidaczniają się zwłaszcza w większych systemach logistycznych. Dla porównania wzięto też pod uwagę przedsiębiorstwa małe i mikro, aczkolwiek $\mathrm{z}$ rozbudowaną działalnością logistyczną. Wybrane zostały zarówno te firmy, w których działania spedycyjne i logistyczne realizowane są samodzielnie (przez wewnętrzne jednostki przedsiębiorstwa), jak również inne, w których spedycja i logistyka powierzana jest zewnętrznym usługodawcom.

Ostatecznie kwestionariusz ankiety skierowano do ok. 300 firm. Odpowiedzi uzyskano jednakże tylko od 59 przedsiębiorstw, co było spowodowane głównie znaczną obszernością kwestionariusza badawczego. Firmy te opisano w tabeli 4 . Jako obiekty badań wybrano zatem firmy wyrażające gotowość do współpracy (wiele przedsiębiorstw odmówiło). Istotne znaczenie miały także pozytywne doświadczenia ze współpracy z nimi w ramach innego rodzaju przedsięwzięć oraz korzystne relacje $\mathrm{z}$ menedżerami $\mathrm{z}$ tych firm.

Respondentami byli pracownicy badanych przedsiębiorstw, zajmujący stanowiska kierownicze i wykonawcze oraz realizujący swoje zadania $w$ ramach procesów logistycznych. Konkretne osoby zostały wybrane po rozpoznaniu specyficznych zasad organizacji i funkcjonowania każdego z analizowanych systemów logistycznych.

Kwestionariusz przesyłano i odpowiedzi uzyskiwano drogą mailową, a w niektórych przypadkach (braków odpowiedzi, wątpliwości, zbytniej ogólności stwierdzeń itp.) przeprowadzono wywiady uzupełniające. Jako narzędzia uzupełniające wykorzystano także studia przypadków i analizę dokumentacji (głównie organizacyjnej, produkcyjnej i technicznej).

Badania przeprowadzono w pierwszej połowie 2018 roku, a ich wyniki i wnioski opracowano w jesieni tego samego roku.

Tabela 4. Charakterystyka badanych przedsiębiorstw

\begin{tabular}{|c|c|}
\hline Cecha & Opis \\
\hline Profil działalności & $\begin{array}{l}\text { Usługowe - } 24 \text {, produkcyjne }-13 \text {, handlowe }-6 \text {, dostawcy usług logistycznych }-6 \text {, handlowo-usługowe }-7 \text {, } \\
\text { produkcyjno-handlowo-usługowe }-3 \text {. }\end{array}$ \\
\hline $\begin{array}{l}\text { Forma } \\
\text { organizacyjno-prawna }\end{array}$ & $\begin{array}{l}\text { Spółka z ograniczoną odpowiedzialności (35). Pozostałe to: spółka akcyjna (10), spółka z ograniczoną } \\
\text { odpowiedzialnością spółka komandytowa (3), spółka komandytowa (2), spółka jawna (1), inne (8). }\end{array}$ \\
\hline $\begin{array}{l}\text { Wielkość (mierzona } \\
\text { liczba zatrudnionych) }\end{array}$ & $\begin{array}{l}\text { Większość (24) stanowiły przedsiębiorstwa duże zatrudniające powyższej } 250 \text { pracowników, } 19 \text { to przedsiębiorstwa } \\
\text { średniej wielkości (od } 50 \text { do } 249 \text { pracowników), } 10 \text { - małe (zatrudniające od } 10 \text { do } 49 \text { pracowników) i } 6 \text { - mikro (poniżej } \\
\text { 10). }\end{array}$ \\
\hline $\begin{array}{l}\text { Zakres współpracy } \\
\text { logistycznej }\end{array}$ & $\begin{array}{l}17 \text { przedsiębiorstw współpracuje z dostawcami usług spedycyjnych, } 22 \text { z dostawcami usług logistycznych, } 16 \text { z nich } \\
\text { współpracuje w obydwu tych zakresach, a } 4 \text { nie współpracują w żadnym. }\end{array}$ \\
\hline Zakres działalności & $\begin{array}{l}17 \text { miało charakter międzynarodowy, } 16 \text { - regionalny, } 13 \text { - krajowy, } 7 \text { - europejski, } 3 \text { - krajowy i międzynarodowy, } \\
3 \text { - krajowy, europejski i międzynarodowy. }\end{array}$ \\
\hline Lokalizacja & $\begin{array}{l}32 \text { zlokalizowanych jest na terenie województwa małopolskiego, } 11 \mathrm{w} \text { województwie mazowieckim, } 9 \mathrm{w} \text { śląskim, } \\
3 \mathrm{w} \text { wielkopolskim, } 2 \mathrm{w} \text { podkarpackim i po } 1 \mathrm{w} \text { opolskim i dolnośląskim. }\end{array}$ \\
\hline
\end{tabular}




\section{Wyniki badań}

$\mathbf{R}$ ezultaty prac badawczych w zakresie pierwszego pytania dotyczącego zasad mediacji menedżerskiej pozwalają na stwierdzenie, że, ogólnie rzecz biorąc, zasady te są $\mathrm{w}$ odpowiednim zakresie wykorzystywane w kierowaniu konfliktami w analizowanych systemach logistycznych. Przedstawiciele około połowy, tj. 30 przedsiębiorstw uznali bowiem, że te zasady są u nich stosowane bardzo często lub często.

Konkretyzując, można zauważyć, że w większości firm przestrzega się najważniejszych spośród tych zasad, tzn. proces mediacji jest przede wszystkim zorientowany na przyszłość oraz postrzegany w kontekście efektywności działania przedsiębiorstwa, a strony mogą swobodnie przedstawić swoje stanowiska i argumenty, bez żadnych ograniczeń formalnych, merytorycznych, czasowych, przestrzennych itp. W 28 badanych firmach stanowiska i argumenty stron często lub bardzo często są prezentowane w otwartej, rzeczowej i szczerej atmosferze, a w proces rozwiązania konfliktu we właściwym czasie włącza się mediator.
Ponadto mediator nie dokonuje zwykle przedwczesnych ingerencji lub nie pozostawia stron konfliktu bez wsparcia, gdy jest ono faktycznie niezbędne oraz pomaga stronom właściwie zidentyfikować problemy stanowiące podłoże konfliktu. Zdaniem przedstawicieli 27 ankietowanych firm, mediator najczęściej wspomaga strony w poszukiwaniu przez nie rozwiązań problemów, inspiruje i zachęca do kreatywnego działania. Respondenci podkreślili, że każda propozycja rozwiązania konfliktu jest brana pod uwagę, nie lekceważy się i nie odrzuca jakichkolwiek merytorycznych sugestii stron konfliktu - taka sytuacja ma miejsce często lub bardzo często w 26 analizowanych przedsiębiorstwach.

W celu uzupełnienia danych dotyczących odpowiedzi respondentów, ujętych na rysunku 1, wyznaczono średnie oceny częstotliwości występowania 17 zasad mediacji (tab. 3) w kierowaniu konfliktami dla pojedynczego systemu logistycznego. Uzyskane wskaźniki ujęto w tabeli 5. Wskaźniki te potwierdzają zamieszczone wcześniej stwierdzenia. Wszystkie odzwierciedlają częste stosowanie poszczególnych zasad mediacji. Najwyższe wartości dotyczą najważniejszych reguł, odzwierciedlających

Tabela 5. Wskaźniki oceny częstotliwości występowania zasad mediacji menedżerskiej w kierowaniu badanymi konfliktami (średnie dla pojedynczego systemu)

\begin{tabular}{|c|c|}
\hline Zasady mediacji menedżerskiej w kierowaniu konfliktami & $\begin{array}{l}\text { Średni wskaźnik } \\
\text { oceny }\end{array}$ \\
\hline Stanowiska i argumenty stron są prezentowane w otwartej, rzeczowej i szczerej atmosferze. & 4,41 \\
\hline $\begin{array}{l}\text { Mediator włącza się w proces rozwiązania konfliktu we właściwym czasie - nie dokonuje przedwczesnych ingerencji lub } \\
\text { nie pozostawia stron konfliktu bez wsparcia, gdy jest ono faktycznie niezbędne. }\end{array}$ & 4,38 \\
\hline $\begin{array}{l}\text { Proces mediacji jest zorientowany na przyszłość, a nie nadmierne analizowanie przeszłości oraz postrzegany } \\
\text { w kontekście efektywności działania firmy. }\end{array}$ & 4,53 \\
\hline $\begin{array}{l}\text { Mediator wspomaga strony w poszukiwaniu przez nie rozwiązań problemów, inspiruje i zachęca do kreatywnego } \\
\text { działania. }\end{array}$ & 4,45 \\
\hline $\begin{array}{l}\text { Mediator pomaga stronom właściwie zidentyfikować problemy stanowiące podłoże konfliktu, eliminując z rozważań } \\
\text { kwestie osobiste i interpersonalne - wzajemne pretensje, żale, urazy itp. }\end{array}$ & 4,41 \\
\hline $\begin{array}{l}\text { Strony mogą swobodnie przedstawić swoje stanowiska i argumenty, bez żadnych ograniczeń merytorycznych, } \\
\text { czasowych, przestrzennych itp. }\end{array}$ & 4,33 \\
\hline Występuje równoprawność stron w całym procesie mediacji. & 4,34 \\
\hline $\begin{array}{l}\text { Każda propozycja rozwiązania konfliktu jest brana pod uwagę, nie lekceważy się i nie odrzuca jakichkolwiek } \\
\text { merytorycznych sugestii stron konfliktu. }\end{array}$ & 4,23 \\
\hline Mediator pomaga w jasnym i jednoznacznym sformułowaniu porozumienia. & 4,29 \\
\hline $\begin{array}{l}\text { Mediator jest bezstronny i akceptowany przez strony, nie opowiada się po żadnej z nich oraz potrafi zachować niezbędny } \\
\text { dystans do nich, siebie i samego konfliktu. }\end{array}$ & 4,13 \\
\hline Mediator efektywnie aranżuje proces mediacji i wyjaśnia stronom, jakie są ich role, oczekiwania wobec nich. & 4,15 \\
\hline Mediator ustala zasady prowadzenia dyskusji i konsekwentnie ich przestrzega. & 4,06 \\
\hline Mediator podsumowuje wypowiedzi stron, powstrzymując się od przedwczesnych, pochopnych ocen. & 4,12 \\
\hline Mediator obiektywnie ocenia postępowanie stron i przebieg procesu mediacji. & 4,04 \\
\hline W razie konieczności mediator spotyka się z każdą ze stron z osobna. & 4.02 \\
\hline Wypowiedzi stron nie są z jakiegokolwiek powodu przerywane. & 3,77 \\
\hline Po rozstrzygnięciu konfliktu mediator gratuluje pracownikom konstruktywnego rozwiązania konfliktu. & 3,75 \\
\hline
\end{tabular}

Źródło: opracowanie własne na podstawie: Pieczonka, 2019, s. 264-265 


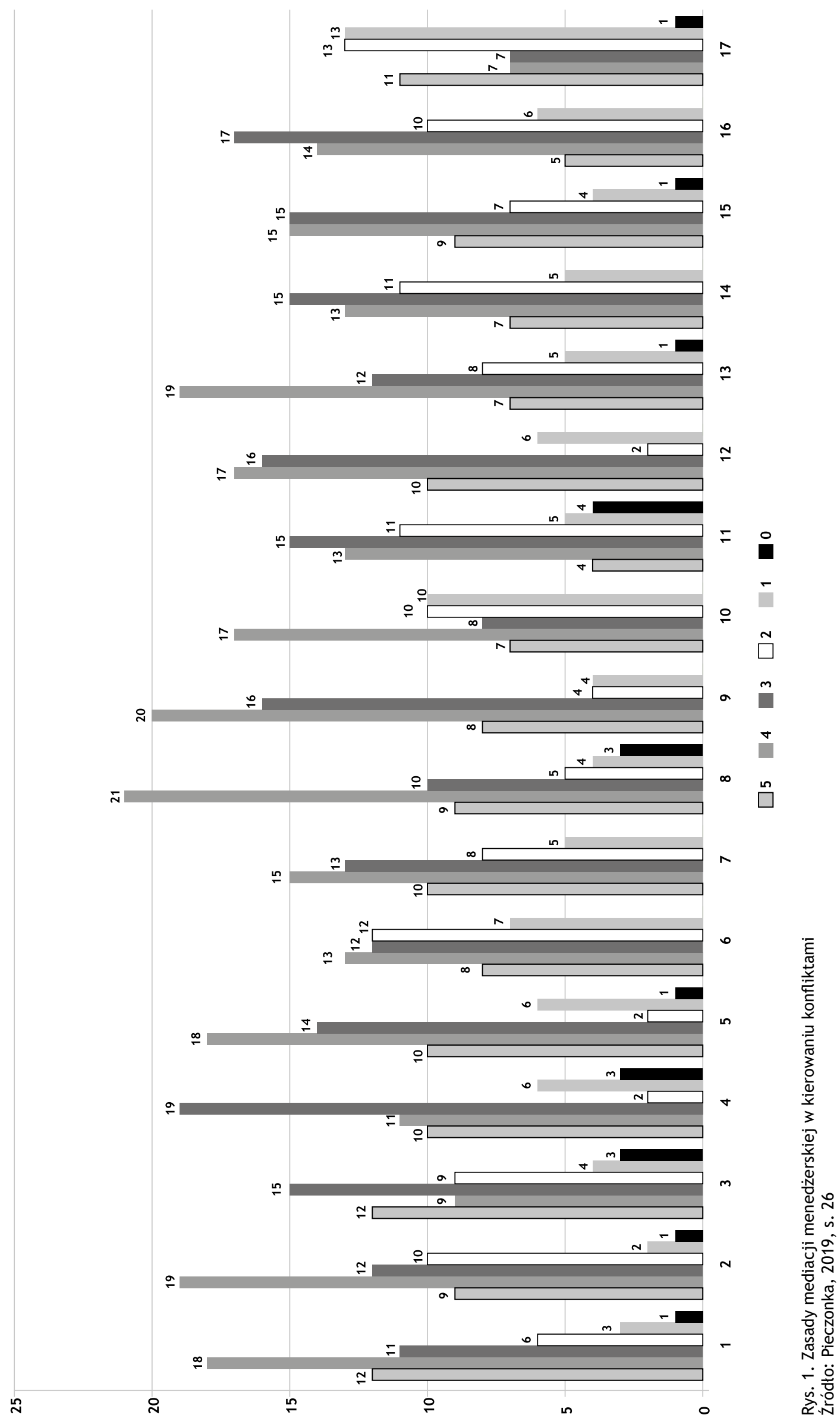


relacje pomiędzy menedżerami jako mediatorami a pracownikami - stronami konfliktu oraz najważniejszy kontekst mediacji, tj. efektywność działania firmy.

Jeśli chodzi o drugie z pytań na temat mediacji, to niektórzy ankietowani podali jej przykładowe opisy w przypadku konfliktów, które wystąpiły w niektórych systemach logistycznych. Są one następujące (zachowano oryginalne sformułowania $\mathrm{z}$ ankiet):

1. W przypadku konfliktu między działami organizacji lub realizowanymi procesami mediacja oparta na analizie „twardych” dowodów, faktów, liczb i danych oraz unikaniu argumentów niemerytorycznych. W toku mediacji konsekwentnie dąży się do ustalenia zmiany obowiązujących zasad współpracy bądź stworzenia nowych, które pomogą uniknąć konfliktów pomiędzy stronami lub choćby zmniejszą prawdopodobieństwo ich wystąpienia $\mathrm{w}$ przyszłości. W ekstremalnych sytuacjach podejmowane są „trudne” decyzje personalne.

2. Pojawiający się konflikt między organizacjami współpracującymi wymaga interwencji menedżera wyższego szczebla zarządzania. $Z$ reguły udaje się wypracować zasady i procedury na przyszłość. Jeśli ma się partnera po drugiej stronie, dobrym sposobem „ułożenia” współpracy jest prezentacja realnych możliwości organizacyjno-operacyjnych. Nie zawsze jednak te możliwości spełniają oczekiwania drugiej strony.

3. Konflikt wystąpił pomiędzy przewoźnikiem a pracownikiem działu obsługi klienta, którzy mieli odmienne zdanie na temat charakterystyki jednego z numerów $\mathrm{UN}$ (tj. kodu towaru niebezpiecznego zgodnie $\mathrm{z}$ umową międzynarodową ADR). Mediatorem został doradca DGSA. Przeprowadził stronom szkolenie. Okazało się, że obie strony konfliktu nie miały racji.

4. Podwykonawca notorycznie zalegał $\mathrm{z}$ zadaniami wobec klienta (na etapie ofertowania i po wykonaniu usługi na etapie obsługi posprzedażowej), sprawiając wiele trudności w pracy działowi obsługi klienta. Dyrektor sprzedaży przeprowadził rozmowę z podwykonawcą, definiując problemy, ich skutki i oczekiwania drugiej strony - działu obsługi klienta. Przeprowadził następnie rozmowę $\mathrm{z}$ pracownikami działu w celu uzyskania aprobaty dla uzgodnień z podwykonawcą. Ustalenia i obopólna na nie zgoda zostały zakomunikowane obu stronom werbalnie.

5. Kierownik, pełniąc $\mathrm{z}$ jednej strony rolę przełożonego, a $\mathrm{z}$ drugiej mediatora, może podać merytoryczne powody podjęcia swojej decyzji, która była początkiem konfliktu. Wyjaśniając wszystkim stronom, jakie były przesłanki, wysłuchując zastrzeżeń oraz czasami gotowych rozwiązań uczestników konfliktu, można wprowadzić nowe lepsze rozwiązanie w duchu wygrany-wygrany.

6. Wkroczenie mediatora jest ostatecznością. Przykładem są procedury, które nie są spójne, a każda ze stron (równorzędna ze względu na status w strukturze organizacyjnej) uważa, że ich procedura jest nadrzędna. W tym przypadku konflikt rozstrzyga zarząd/prezes zarządu.

7. Proces mediacji przebiega następująco: Najpierw odbywa się rozpoznanie konfliktu, tj. jego rodzaju, stron, ich interesów, żądań itp. oraz jego przyczyn. Z kolei istotne jest określenie jego plusów oraz minusów, a zwłaszcza pozytywnych i negatywnych skutków. Wreszcie doprowadza się do rozmów ugodowych oraz przekonuje strony do ustępstw.

8. Punktem wyjścia do mediacji jest przedstawienie stronom konfliktu problemu z punktu widzenia przedsiębiorstwa jako całości. Dokonywana jest obiektywna ocena rozwiązania proponowanego do przyjęcia $\mathrm{z}$ uwzględnieniem wynikających $\mathrm{z}$ niego niedogodności dla każdej ze stron, które muszą być podporządkowane nadrzędnemu celowi, jakim jest interes firmy jako całości.

9. Problem dotyczy uszkodzenia palet w trakcie dostawy. Strony konfliktu to firma transportowa oraz zleceniodawca. Mediatorem jest niezależna osoba z zewnątrz. Organizuje się spotkanie obu stron, podczas którego mogą one spokojnie przedstawić swoje argumenty za i przeciw oraz poszukać wzajemnie akceptowalnych rozwiązań.

Jak pokazują powyższe przykłady, w badanych systemach logistycznych przedsiębiorstw mediacje są realizowane we właściwy sposób (Pieczonka, 2019, s. 265-266). Uwzględnia się zaangażowanie kierownictwa (bezpośrednich przełożonych lub nawet kierownictwa najwyższego szczebla zarządzania). Podkreślane jest znaczenie rozpoznania przyczyn konfliktu, przygotowania stron do wdrożenia rozwiązań mających zapobiec powstawaniu podobnych sytuacji $\mathrm{w}$ przyszłości. Zaangażowanie kierownictwa, zwłaszcza w warunkach ograniczonych kompetencji osób na tych stanowiskach w prowadzeniu mediacji może jednak prowadzić do autorytarnego zastosowania zasad takich mediacji. Sprzyja to podejmowaniu przez nich działań ad hoc. W przedstawionych przykładach w niewielkim stopniu uwzględnia się także kwestię uczenia się na podstawie uczestnictwa w konfliktach oraz $\mathrm{w}$ mediacjach związanych $\mathrm{z}$ ich rozwiązywaniem.

\section{Podsumowanie}

$\mathbf{R}$ easumując, wnioski z prac badawczych dotyczących wykorzystywania zasad mediacji w rozwiązywaniu konfliktów organizacyjnych w systemie logistycznym są trojakiego rodzaju.

1. Konkluzje teoretyczne, tj. uogólnienia wyprowadzone z badań empirycznych. Oceniając sposób wykorzystania zasad mediacji menedżerskiej w procesie kierowania konfliktami organizacyjnymi w analizowanych przedsiębiorstwach, przede wszystkim pozytywnie należy ocenić to, że zasady te są często stosowane w tym procesie. Należy także podkreślić, że ze względu na to, iż rozważane konflikty mają charakter wewnątrzorganizacyjny (w związku z ustalonym zakresem prac badawczych), rolę mediatora pełni zwykle przełożony odpowiedniego szczebla, odpowiedzialny za rozwiązywanie konfliktów w podległej mu jednostce organizacyjnej. Istotne jest również to, że w ponad połowie badanych przedsiębiorstw kierownicy jako mediatorzy potrafią skutecznie orientować się na przyszłość, a nie na przeszłość, nie piętnując 
przy tym podwładnych za powstawanie konfliktów oraz nie urządzając „polowań na czarownice”. Potrafią także postrzegać konflikty z szerszej perspektywy, tj. w kontekście efektywności działania całego przedsiębiorstwa. W większości umieją stworzyć podwładnym odpowiednie warunki do swobodnego przedstawiania ich stanowisk i argumentów w otwartej, rzeczowej i szczerej atmosferze. Włączają się w procesy rozwiązywania konfliktów w odpowiednim czasie, pomagając stronom obiektywnie zidentyfikować problemy stanowiące podłoże sporów i niegodności. Z drugiej jednak strony, niektóre zasady mediacji zostały uznane przez respondentów za mniej istotne. Do takich zasad należy np. zasada integracji, związana $\mathrm{z}$ zaangażowaniem przełożonego (mediatora) we wzmacnianie u uczestników konfliktu przekonania o konstruktywnym charakterze osiągniętego rozwiązania konfliktu. Można zatem stwierdzić, iż przyjęta na wstępie hipoteza została potwierdzona częściowo, tzn. rozważane zasady mediacji są przydatne do rozwiązywania omawianych konfliktów.

2. Rekomendacje praktyczne, których celem jest usprawnienie procesu zarządzania konfliktami w systemie logistycznym, co znajduje odzwierciedlenie w poziomie efektywności funkcjonowania całej organizacji. Pomimo generalnie pozytywnej oceny wykorzystania zasad mediacji w tym procesie, można przedstawić trzy istotne sugestie jego udoskonalenia $\mathrm{w}$ badanych przedsiębiorstwach, biorąc pod uwagę najniższe wskaźniki wykorzystania zasad mediacji $\mathrm{z}$ tabeli 5 oraz odpowiedzi na pytania otwarte (zwłaszcza niektóre stwierdzenia ukryte „między wierszami”). Po pierwsze, niezbędne jest poszerzenie zakresu wykorzystania mediacji jako narzędzia kierowania konfliktami oraz wypracowanie procedur w tym zakresie. Precyzyjne regulacje pozwoliłyby na sprawniejsze identyfikowanie i rozwiązywanie konfliktów. Po drugie, w zakresach zadań, uprawnień i odpowiedzialności zarówno stanowisk kierowniczych, jak i wykonawczych, pożądane byłoby zawarcie odpowiednich zapisów co do z jednej strony trybu realizacji mediacji, a $z$ drugiej - sposobu zachowania się w jej trakcie. Po trzecie, sugerowane zmiany powinny być wspomagane przeprowadzeniem szkoleń w formie interaktywnej (treningów i warsztatów) dla wszystkich pracowników w zakresie stosowania mediacji jako metody kierowania konfliktami.

Sugestie udoskonalenia proponowanego modelu zarządzania rozważanymi konfliktami (wzmiankowanego we wprowadzeniu), w tym miejscu w zakresie stosowania zasad mediacji (omówionych w tabeli 3). Uwzględniając powyższe rekomendacje, zaleca się poszerzenie tego modelu, a ściślej jego modułu dotyczącego mediacji o dwa istotne komponenty, adekwatne do tych rekomendacji, tj. wspomagające ich wdrożenie. Po pierwsze, za celowe należy uznać skonkretyzowanie proponowanych zasad mediacji poprzez wskazanie dla każdej z nich szczegółowych funkcji (działań) potrzebnych do jej zastosowania przez menedżerów jako mediatorów. Po drugie, proponowany model należy wzbogacić o zestaw modelowych (wzorcowych) rozwiązań w zakresie praktycznego wykorzystania tych zasad na bazie szeregu studiów przypadków.

Istotnym ograniczeniem rezultatów omawianych prac jest ich zakres. Pożądane byłoby ich poszerzenie o większą liczbę firm-respondentów w badaniach porównawczych. Nie wzięto pod uwagę ilościowych charakterystyk działań mediacyjnych. Ponadto zasadnym byłoby poszerzenie zakresu analizy o szczegółowe sposoby realizacji takich działań, zarówno w typowych, jak i wyjątkowych sporach pomiędzy pracownikami i zespołami.

dr hab. Andrzej Kozina, prof. uczelni Uniwersytet Ekonomiczny w Krakowie Wydział Gospodarki i Administracji Publicznej ORCID: 0000-0001-8973-8279 e-mail: kozinaa@uek.krakow.pl

dr Tomasz Małkus

Uniwersytet Ekonomiczny w Krakowie

Wydział Zarządzania

ORCID: 0000-0002-7978-4295

e-mail: malkust@uek.krakow.pl

\section{dr Agnieszka Pieczonka}

Politechnika Krakowska im. T. Kościuszki

Centrum Organizacji Szkoleń i Systemów Jakości

ORCID: 0000-0003-1663-2611

e-mail: a.pieczonka@pk.edu.pl

\section{Przypis}

1) Podstawę do opracowania artykułu stanowił projekt finansowany w ramach programu Ministra Nauki i Szkolnictwa Wyższego pod nazwą „Regionalna Inicjatywa Doskonałości” w latach 2019-2022 nr projektu: 021/RID/2018/19, kwota dofinansowania: 11897 131,40 zł.

\section{Bibliografia}

[1] Bargiel-Matusiewicz K. (2014), Negocjacje i mediacje, PWE, Warszawa.

[2] Barutçu S., Doöan H., Barutçu E., Kulakli A. (2010), Supply Chain-Based Conflict: A Study from Textile Exporters' Perspectives, „Journal of Global Strategic Management”, Vol. 4, No. 2, pp. 90-102.

[3] Blaik P. (1999), Logistyka, PWE, Warszawa.

[4] Christopher M. (2000), Logistyka i zarzadzanie łańcuchem dostaw. Strategie obniżki kosztów i poprawy poziomu usług, Polskie Centrum Doradztwa Logistycznego, Warszawa.

[5] Cloke K., Goldsmith J. (2011), Resolving Conflicts at Work: Ten Strategies for Everyone on the Job, Jossey-Bass, San Francisco. 
[6] Colosi T. (1993), The Role of the Mediator, [in:] R.J. Lewicki, J.A. Litterer, D.M. Saunders, J.W. Minton, Negotiation. Readings, Exercises \& Cases, Irwin, Homewood, Boston, pp. 466-473.

[7] Cousins R.B., Benitz L.E. (1994), Every Supervisor Needs Mediation Skills, „Supervision”, May, pp. 10-14.

[8] Długosz J. (2000), Integracyjna funkcja logistyki w zarzadzaniu celami przedsiębiorstwa, Ruch Prawniczy, Ekonomiczny i Socjologiczny, rok LXII, zeszyt 4, s. 103-119.

[9] Doherty N., Guyler M. (2008), The Essential Guide to Workplace Mediation and Conflict Resolution, Kogan Page Ltd., London.

[10] Garbarski L., Rutkowski I.P., Wrzosek W. (2000), Marketing. Punkt zwrotny nowoczesnej firmy, PWE, Warszawa.

[11] Gitling M. (2013), Człowiek w organizacji: ludzie, struktury, organizacje, Difin, Warszawa.

[12] Gmurzyńska E., Morek R. (red.), (2018), Mediacje. Teoria i praktyka, Wolters Kluwer Polska, Warszawa.

[13] Handfield R.B., Baumer D.L. (2006), Managing Conflict of Interest Issues in Purchasing, „Journal of Supply Chain Management”, Vol. 42, No. 3, pp. 41-50.

[14] John F.R., Prasada P.S.S. (2012), An Overview of Conflicts in Supply Chain Systems, „International Journal of Logistics Systems and Management", Vol. 11, No. 3, pp. 7-27.

[15] Jones T.S., Brinkert R. (2008), Conflict Coaching, Sage Publications, Thousand Oaks.

[16] Killman R.H., Thomas K.W. (1978), Four Perspectives on Conflict Management: An Attributional Framework for Organizing Descriptive and Normative Theory, „The Academy of Management Review", Vol. 3, No. 1, pp. 8-22.

[17] Kisperska-Moroń D. (1999), Konflikty w łańcuchach dostaw, „Gospodarka Materiałowa i Logistyka”, nr 2, s. 25-31.

[18] Krysiuk C., Zakrzewski B., Zakrzewska D. (2014), Konflikt $i$ jego rola $w$ przedsiębiorstwie logistycznym - ujęcie teoretyczne, „Logistyka”, Nr 6, s. 6164-6176.

[19] Michlowicz E. (2002), Podstawy logistyki przemysłowej, Wydawnictwa AGH, Kraków.

[20] Moore C. (1993), How Mediation Works, [in:] R.J. Lewicki, J.A. Litterer, D.M. Saunders, J.W. Minton, Negotiation. Readings, Exercises \& Cases, Irwin, Homewood, Boston, pp. 445-465.

[21] Moore C.W. (2009), Mediacje. Praktyczne strategie rozwiązywania konfliktów, Wolters Kluwer Polska sp. z o.o., Warszawa

[22] Pereseina V., Jensen L.-M., Hertz S., Cui L.(2014), Challenges and Conflicts in Sustainable Supply Chain Management: Evidence from the Heavy Vehicle Industry, „Supply Chain Forum: An International Journal", Vol. 15, No. 1: Sustainable Supply Chains, pp. 22-32.

[23] Pfohl H.C. (1998), Zarzadzanie logistyka. Funkcje $i$ instrumenty. Zastosowanie koncepcji logistyki $w$ przedsiębiorstwie i $w$ stosunkach między przedsiębiorstwami, Biblioteka Logistyka, Poznań.

[24] Pieczonka A. (2019), Model zarządzania konfliktami organizacyjnymi w systemie logistycznym przedsiębiorstwa, rozprawa doktorska, Uniwersytet Ekonomiczny w Krakowie, Wydział Ekonomii i Stosunków Międzynarodowych, Kraków.
[25] Pruitt D.G., Rubin J.Z. (1986), Social Conflict. Escalation, Stalemate, and Settlement, McGraw-Hill, Inc., New York.

[26] Rahim M.A. (1986), Managing Conflict in Organizations, Praeger Publishers, New York.

[27] Roche W.K., Teague P., Colvin A.J.S. (eds.), (2014), The Oxford Handbook of Conflict Management in Organizations, Oxford University Press, Oxford.

[28] Szymonik A., Bielecki M. (2015), Bezpieczeństwo systemu logistycznego w nowoczesnym zarządzaniu, Difin, Warszawa.

[29] Wallenburg C.M., Raue J.S. (2011), Conflict and Its Governance in Horizontal Cooperations of Logistics Service Providers, „International Journal of Physical Distribution \& Logistics Management”, Vol. 41, No. 4, pp. 552-575.

[30] Zakrzewski B., Zakrzewska D.(2014), Zarządzanie konfliktem $w$ przedsiębiorstwie logistycznym $w$ aspekcie przywództwa - ujęcie teoretyczne, „Logistyka” Nr 6, s. 1154711556.

\section{Principles of Mediation in Solving Organizational Conflicts within the Enterprise's Logistics System}

\section{Summary}

The objective of the paper is to present the findings of the research on the application of mediation principles in solving organisational conflicts within the enterprise's logistics system. Firstly, the interpretations of basic concepts are presented, i.e. the company's logistics system, organisational conflict, the model of managing conflicts within the enterprise's logistics system and mediation as well as the original concept of its principles (as the theoretical basis of the research). Secondly, the research methods are discussed, in particular the survey questionnaire, which was an essential tool for the empirical research. Thirdly, its results are summarised. Finally, the summary comprises conclusions from those studies, i.e. theoretical findings, practical recommendations and suggestions for the improvement of the suggested model of managing the considered conflicts. On the one hand, it has been found that both the scope of application of mediation principles to resolve the considered conflicts by managers within the analysed systems, and the level of mediation efficiency are satisfactory. On the other hand, in some cases, the scope of mediation can and should be expanded, and procedures and rules for its implementation should be developed. It is also desirable to provide training for managers to improve their mediation competences. It is also necessary to develop model solutions in the scope of methods and means of mediation based on broader comparative empirical research.

\section{Keywords}

mediation, organisational conflict, enterprise's logistics system, managing organisational conflict in enterprise's logistics system 